\title{
VANWAAR DIE KRAGTIGE INVLOED VAN DIE OPTREDE EN PREDIKING VAN JESUS?*
}

Onder hierdie opskrif wil ons nagaan waaraan dit toe te skryf is, dat die Evangelie van Jesus ingang gevind het in die harte van die wat Hom gehoor het, en daarna uitgebrei het na alle volke. Wat was dit wat daartoe meegewerk het, dat die Evangelie posgevat het in 'n heidense wêreld waar geen kennis van die Lewende God bestaan het nie? En, veral, waaraan is dit te danke dat Jesus soveel volgelinge onder die Joodse volk gekry het, ten spyte daarvan dat die leidende geeste van daardie volk Hom so uitdruklik vyandig gesind was?

Hierdie vrae kan ons maklik beantwoord met die eenvoudige bewering dat Jesus deur God gestuur was en dat Hy Godswerk gedoen het, daarom kon die seën op sy werk nie uitbly nie.

Dit is waar, maar dit sê tog nie genoeg nie. God bedien Hon vir die bevordering van sy werk van middels. Daarom moet ons nagaan van welke middels hier gebruik gemaak is. Hoe is die bodem deur God vrugbaar gemaak, en hoe het Jesus op daardie vrugbare, bewerkte bodem gesaai?

Daar kan dan vir die kragtige invloed van Jesus twee reekse oorsake aangegee word. Die eerste wil ek noem Uitwendige Oorsake en die tweede Inwendige Oorsake. Onder die uitwendige oorsake wil ek behandel die geestelike en godsdienstige toestand van die wêreld waarin die Evangelie uitgedra moes word, met spesiale behandeling van die toestande van die Joodse volk ten tye van die optrede van Jesus. Onder die inwendige oorsake kom in behandeling die persoon like optrede en manier van prediking van Jesus self, met enkele verwysings na die prediking van die Apostels. Miskien is dit wenslik om hier net vas te stel, dat ons altyd uitgaan van die veronderstelling dat die gegewens van die Heilige Skrif die waarheid is, ten spyte daarvan dat baie geleerdes van baie tye sommige gedeeltes van die Heilige Skrif as latere toevoegings en dus as van tweederangse waarde vir die behandeling van die lewe en werk van Jesus beskou.

Daar staan in Gal. 4:4 "Maar toe die volheid van die tyd gekom het. het God sy Seun uitgestuur." En Johannes die Dooper bevestig hierdie standpunt as hy sê: „Die Koninkryk van God het naby gekom." Jesus het gekom in die volheid van die tyd, d.w.s. toe die tyd ryp was vir sy koms, toe die toestande in die wêreld so was dat sy Evangelie vrugte kon dra.

In hierdie verband wil ons dan in die eerste plek met enkele opmerkings die godsdienstige toestande van die Hellenistiese wêreld

*Referaat gehou voor die Predikante-vergadering op 21 Februarie, 1945. 
beskryf as vrugbare bodem vir die Evangelie. Prof. Brouwer ${ }^{1}$ ) wys in "Inleiding tot den Bijbel" daarop dat daar in die Hellenistiese wêreld in die tyd van Jesus 'n sterk godsdienstige behoefte was. Terwyl WooLF ${ }^{2}$ ) die bewering maak dat, alhoewel daar geen sterk sondebesef was nie, daar tog 'n wydverspreide verlange na verlossing was. Daar is uitgesien na in Verlosser, nie alleen in Judea en Galilea nie, maar ook in elke ander land, alhoewel dit by die heidense volkere met minder vertroue en profetiese entoesiasme was. Miskien was hierdie verlange meer na verlossing uit tydelike nood; die begeerte dat die sterwe wins moes wees, het, in elk geval, nie helemal ontbreek nie. Hierdie feit dat ook die heidense volkere van die Hellenistiese wêre!d, waar die Christendom sy wortels moes uitsprei, 'n sterk godsdienstige behoefte gehad het, word verder bevestig as mens dink aan die plekke van aanbidding $\mathrm{nl}$. die ou Tempels.

DeIsSMANN ${ }^{3}$ ) maak oor die ou Tempels die volgende opmerking: „Die skoonheid en prag van hierdie heilige plekke verruim die hart vir ernstige toewyding, en die grootsheid en grootheid daarvan laat die hart bewende neersink voor die geweldige en verhewene." Ons kan in hierdie verband ook dink aan die Atheners wat selfs n altaar vir die onbekende God gehad het. Dit openbaar die diepe godsdienstige behoefte en aanleg van die volkere van daardie tyd soos wat Paulus dit tereg opgemerk het.

DeISSANN ${ }^{4}$ ), wat self 'n uitgebreide studie van die gegewens wat die papyri oor die privaat lewe van die mense van die gewone volkslae verstrek, gemaak het, sê dat wanneer in hierdie verband so ver gevorder is dat mens 'n persoonsregister van die mense van die gewone volkslae kan opstel, dit baie duidelik verstaan sal word hoe die Christelike geloof juis in hulle behoeftes kon voorsien het. Daardie droomgesig van Paulus waar 'n Macedoniese man voor hom staan met die bede: ,Kom oor en help ons," ${ }^{5}$ ) word dan byna werklikheid.

Daar was dus ' $n$ sterk ontwikkelde godsdienstige behoefte by die volke waarna die Evangelie van Jesus in die eerste jare van sy bestaan uitgedra moes word. Dit is waar dat die mense van alle tye 'n godsdienstige behoefte gevoel het, maar, in die tyd net voor die koms van Christus het dit so ontwikkel, dat daardeur aan die eenkant 'n vrugbare bodem vir die Evangelie geskep is, en, aan die ander kant, het die godsdienstige filosofie van die antieke wêreld sigself op 'n dooie punt

1) Dr. H. Th. Obbink en Dr. A. M. Brouwer: Inleiding tot den Bijbel (Amtserdam 1928). p. 209.

2) B. L. Woolf: The Authority of Jesus and its Foundation. (London 1929). p. $43-44$.

3) Adolf Deissmann: Light from the Ancient East. (Engelse vertaling van L. R M. Strachan, London, 1911) p. 285.

4) Ib. p. 302 .

5) Hand. 16:9. 
vasgeloop wat vir die sielsbehoeftes van die mens geen bevrediging kon bring nie.

Die antieke wysheid het slegs met weifelende stem die belofte van onsterflikheid en ewige lewe gebring.

PROF. DE ZWAAN haal in sy boekie: „Antieke Cultuur om en agter het Nieuwe Testament" van Seneca die volgende bewering aan: „die klein tydjie van ons sterflike lewe is slegs die voorspel van 'n beter en langdurige bestaan. Tien maande, sê hy, duur die voorbereiding van ons geboorte.... voor ons kon asemhaal en voor ons ons as lewende wesens op die aarde bevind. So is ons ook in die tussenruimte wat ons jeug van ons ouderdom skei, besig om ryp te word vir 'n nuwe geboorte. 'n Ander begin, ' $n$ ander werklikheid wag vir ons." ${ }^{6}$ )

So 'n geloof wat ' $n$ ander lewe na die dood voorhou, moes 'n vrugbare akker oplewer vir die Evangelie wat juis kom met die belofte op die ewige lewe.

Maar, aan die anderkant, omdat daar by hierdie filosofie die sondebesef ontbreek het, omdat die hoop op onsterflikheid alleen gewag het vir die goeie mens - hier is slegs 'n soort vergeestelikte natuurwet gespreek: die onedele moes wegsink, en die edele moes kragtens sy eie natuur styg i) - daarom het dit op die oue end op vertwyfeling en wanhoop uitgeloop. Wat moes dan word van die minder goeies, van die wat rede gehad het om aan eie veredeling te twyfel? Hierin het die rede gelê waarom die lug swanger was van hoop en vrees tegelyk.

In so 'n atmosfeer waar daar hoop was op redding, maar tegelyk ook vrees, dat dit alles kon misloop. het die boodskap van die Evangelie as 'n tydige redmiddel gekom wat deur duisende gretig aangegryp is. Ons kans slegs dink aan die tronkbewaarder van Filippi wat niks anders vra as net dit: "Menere, wat moet ek doen om gered te word?" s)

By al die stelsels en beskouinge van die heidense wysbegeerte het daar steeds die sondebesef en die besef van die goddelike geregtigheid ontbreek. Die Stoïcyne het byvoorbeeld geleer dat die wêreld met vuur sal vergaan; maar tog is daar by hulle geen sprake van regverdiging van die opregtes of straf vir die onregverdiges; daar is ook geen sprake van 'n beter wêreld na hierdie een: alles sou maar weer van vooraf aan begin. ${ }^{9}$ )

Waar so 'n wanhoopsprediking die beste was wat aangebied kon word, is dit lig te begrype dat die Evangelie met sy suiwere klanke van regverdiging vir die gelowige, van 'n beter wêreld na hierdie een - 'n nuwe hemel en 'n nuwe aarde waar alle leed en alle vuilheid

6) Prof. J. de ZwaAn: Antieke Cultuur om en achter het Nieuwe Testament. (Haarlem 1926). p. 118.

;) vgl. De ZwaAn: ib. p. 122.

8) Hand. 16:30.

9) DE ZwaAn: ib. p. 141. 
uitgesluit is - dat die Evangelie met sy vaste hoop en sekere toekoms verwagting aanklank moes vind in die harte van hulle wat gedurig tussen die pole van hoop en vrees heen en weer geslinger is.

Die Evangelie het gekom om te voorsien in die behoefte wat deur die heidense filosofie steeds sterker ontwikkel is, maar wat deur daardie filosofiese beskouings nie bevredig kon word nie, nl. die behoefte aan verlossing. Ons wil dan ook graag saamstem met $D_{R}$. DE ZWAAN ${ }^{10}$ ) waar hy sy genoemde werkie afsluit met die opmerking, dat die geheim van die wêreldoorwinnende mag van die Christendom lê in die feit dat dit verlossing predik: die siel word verlos van sy vrees vir 'n doellose wêrelddrama, vir 'n leë heelal en 'n lewe sonder sin en betekenis.

So het daar in geestelike en godsdienstige sin vir die volkere waarheen die draers van die Evangelie sou gaan, werklik die volheid van die tyd aangebreek. God het op sy bestemde tyd sy Seun in die vlees gestuur, sodat sy werk nie vrugteloos sou wees maar veel vrug sou dra.

Maar, voordat daar onder die heidene vrugte gedra kon word, moes daar nog eers verkondigers wees wat die Evangelie onder die heidene kon bekend maak. Daar moes Apostels wees. En hierdie Apostels het gekom uit die Joodse volk, waaruit Jesus ook gebore is. Die eerste akker waarop daar gesaai moes word, sou die Joodse akker wees. Daarom is dit nodig dat ons hier 'n oorsig sal kry van die toestand van die Joodse volk.

Ons wil dan ook kortliks aantoon hoedat die politieke en maatskaplik-ekonomiese toestande van die Joodse volk gedurende die laaste eeu voor Christus meegewerk het om 'n gees van ontvanklikheid. vir die Evangelie te skep, en dan meer breedvoerig die godsdienstige toestande in oënskou neem, want dit is die godsdienstige toestande van die Joodse volk wat in die allereerste plek die regte ontvanklikheid vir die prediking van Jesus geskep het.

Dit was met die Joodse volk gedurende die laaste eeu voor die geboorte van Christus maar kwalik gesteld. Daar was oorheersing deur vreemdes en gedurige twis onder mekaar; hulle was 'n volk sonder staatkundige prestige, en die groot meerderheid was arm mense.

KLAUSNER ${ }^{11}$ ) wys daarop dat, gedurende die eeu net voor en met die lewe van Jesus, daar skaars 'n jaar verbygegaan het sonder oorlog, rebellies en opstande. Daar is bereken dat daar nie minder as 200,000 man in hierdie tyd die lewe gelaat het nie. Dit is wel 'n groot getal as mens in aanmerking neem dat die Joodse volk betreklik klein was. Die wat op die slagvelde gesneuwel het, was die liggaamlik sterkes, en

10) Antieke Cultuur, p. 149.

11) J. Klausner: Jesus of Nazareth. His Life, Times and Teachings. (Engelse vertaling deur Herbert Danby). London 1925, p. 167. 
die wat as gevolg van opstande veroordeel en tereggestel is, was in intellektuele en kulturele sin die bestes onder die volk. Die wat nog in lewe gebly het, was "nie van hierdie wêreld nie." Hulle het die rug gekeer op staatsake, en vir hulle meer verdiep in die godsdiens. Hulle het slegs 'n oog gehad vir die ander lewe. ${ }^{12}$ )

Dit is ook te begrype, as mens dink dat die Joodse volk gedurende hierdie tyd skaars hard kon praat oor staatsake uit vrees dat hulle bespied en beloer word en so beskuldig kon word. ${ }^{13}$ )

'n Treffende voorbeeld van hierdie toestand vind ons ook in die geskiedenis van die genesing van die blinde van Jerigo. Toe hy Jesus hard toeroep: .Seun van Dawid, wees my barmhartig," het die volk hom stilgemaak. ${ }^{14}$ ) Waarom? Nie slegs omdat hulle dit onbehoorlik gevind het dat hy so skreeu nie, maar dit was gevaarlik om iemand uit te roep as Seun van Dawid, as Koning van Israel!

Die Romeine en die Jode kon mekaar eenvoudig nie verstaan nie, en dit het altyd aanleiding gegee tot wrywing, botsings en bloedvergieting.

Hierdie staatkundige nood het min of meer tweërlei uitwerking op die Joodse volk gehad. Aan die eenkant het dit fanatici gekweek wat meestal met hulle bloed moes betaal vir hulle onbesonnenheid, en aan die anderkant het dit by baie berusting gebring. Hierdie groep het gewag op uitkoms van die hemel af. Die profesieë oor die Messias het lewendig begin lewe. Maar omdat daar so 'n geweldige kloof was tussen die profetiese beloftes en ideaal aan die eenkant en die nood van die werklikheid aan die anderkant, het daar meer en meer die behoefte ontstaan om deur gebed en verootmoediging, deur die vol. brenging van Gods wil, te soek na uitkoms. ${ }^{15}$ ) Dit was veral by die stilles in die land, by die nederiges en eenvoudiges wat hierdie behoefte geheers het en by wie die Messiaanse verwagting dan ook vol verbeelding en mistiek was.

Op ekonomies-maatskaplike gebied was dit met die Joodse volk net so kwalik gesteld. Naas die enkele rykes en 'n groter getal gegoedes, was die oorgrote meerderheid armes; baie was maar huurlinge wat alleen kon lewe van wat hulle met hulle hande verdien het. ${ }^{16}$ ) Ook hier was die uitwerking dat sommiges deur geweld wou probeer om verlos te word uit die nood, en ander het probeer om deur getrouheid aan Gods wil en die volbrenging van Gods wette ' $n$ beter toekoms uit te werk. Tog was daar 'n groep wat, juis omdat hulle geen bevrediging vir hulle sielsbehoeftes deur wetsvervulling kon vind nie, 'n

12) Klausner: ib. p. 167.

13) Baba Bathra 3b, 4a, aangehaal deur Klausner, p. 167.

11) Luk. 18:39.

15) KLAUSNER: p. 189.

16) Klausner: p. 182. 
sterker behoefte aan genade en vergewing ontwikkel het. ${ }^{17}$ ) Die armes en verdruktes wat ook geen bevrediging in wetsvervulling kon vind nie, het gretiglik uitgesien na 'n beter basis van bestaan, en hierdie verwagting is bevredig deur die verkondiging van die Koninkryk van die Hemele. Die wat hierdie behoeftes gehad het, was dan ook veral in Galilea vanwaar die eerste en meeste dissipels van Jesus getrek is. ${ }^{1 *}$ )

So het die staatkundige en ekonomies-maatskaplike nood van die Joodse volk 'n vrugbare bodem vir die optrede en prediking van Jesus gelewer. Dit het meegewerk om die volheid van die tyd te laat aanbreek.

Maar Jesus was nie ' $n$ maatskaplike Hervormer nie, Hy was allermins 'n staatkundige Verlosser. Hy bring 'n boodskap van die ewigheid. Die godsdienstige behoefte van die volk wat Hom hoor, speel dus 'n allerbelangrikste rol. Laat ons dan nagaan hoe die godsdienstige toestande van die Joodse volk meegewerk het om 'n ontvanklike hart by sy hoorders te skep.

In die eerste plek moet ons daarop.wys dat hierdie politieke en maatskaplike nood die Joodse volk geleer het om die oog na die toekoms te rig. Die verwagting van die Messiaanse ryk was egter nie soos ons dit in Christelike sin verstaan nie. Ons kan eerder praat van die verwagting van 'n goue eeu by Israel. ${ }^{19}$ ) Maar hierdie goue eeu sou nie alleen politieke en ekonomiese onafhanklikheid meebring nie. Dit sou ook 'n eeu wees waarin almal die Here ken. ${ }^{.0}$ ) Toe Israel na die ballingskap egter nie as onafhanklike ryk herstel is nie, het hierdie verwagting sterker na vore gekom, terwyl dit tewens ook 'n verdieping van inhoud ondergaan het, alhoewel die "Home rule party" ook altyd sy aanhangers gehad het - die wat die Messiaanse ryk suiwer as politieke verwagting gesien het- n Messiaanse ryk, sonder Messias. ${ }^{21}$ )

KLAUSNER lê ook die nadruk daarop dat die hele volk gedurende hierdie tyd uitgesien het na die koms van die Messias, alhoewel die vorm van die verwagtings nie by almal dieselfde was nie, ${ }^{22}$ ) terwyl DE Z WAAN daarop wys dat die prediking, dat Jesus die Messias is niemand met die verwagting en hoop van 'n Israeliet in die hart onverskillig kon laat nie. ${ }^{23}$ ) As hulle dit betwyfel het dat Jesus die Messias is, moes hulle daarteen in opstand kom, en, as hulle dit geglo het, is hulle verwagtings daardeur verwesenlik.

In verband met hierdie toekomsverwagting het die opkoms van die Joodse apokaliptiek in die laaste twee eeue voor die geboorte van Christus vrugbare aanvoorwerk gedoen. Omdat die apokaliptiek die

17) KLAUSNER: p. 190.

18) KLAuSNER: p. 192.

$19)$ M. E. Enstin: Christian Beginnings. (New York 1938) p. 139.

20) Jeremia $31: 34$

21) vgl. ENSLIN : p. 139 (voetnoot).

22) Klausner : p. 201.

23) DE ZWAAN : p. 138. 
ander lewe beklemtoon het, omdat dit die hoop op die ewige lewe beklemtoon het, omdat dit die gedagte van die opstanding en ewige lewe vir die individu bevorder het, het dit die prediking en die aanneming van die Evangelie moontlik gemaak. ${ }^{2 .}$ ) Ons kan dit tog moeilik aanneem dat die prediking van die Evangelie met sy belofte van verlossing en opstanding vir die enkeling veel aanklank sou vind as hierdie geloof nie reeds sy wortels begin uitskiet het. As Jesus dus in sy prediking daarop wys, dat mens Hom moet vrees wat beide siel en liggaam kan verdelg, dan is dit iets wat al dadelik aanklank by die hoorders kon vind.

Ons kan verder die voorstelling van die "Seun van die Mens" as wêreldregter in die boek Henoch ${ }^{25}$ ) vergelyk met die voorstelling dat Jesus as Regter sal sit om die wêreld te oordeel. ${ }^{26}$ ) Jesus het seif ook op hierdie werksaamheid van Hom as wêreldregter gewys as $\mathrm{Hy}$ sê : „Daarom moet julle ook gereed wees omdat die Seun van die Mens kom in ' $n$ uur dat julle dit nie verwag nie. ${ }^{27}$ )

Deur te wysy op hierdie toekomsverwagting van Israel wat onder leiding van die Apokaliptiek so sterk ontwikkel het in die rigting van geloof aan persoonlike opstanding en ewige lewe is nog nie voldoende grond aangegee waarom die prediking van Jesus sou ingang vind nie. Die ooreenkoms tussen die toekomsverwagting van Jesus soos dit blk uit sy prediking en die toekomsverwagting van die Joodse volk was alleen nie genoeg om die harte na Jesus aan te trek nie. As ons kon aantoon dat ook hier, soos in die geval van die staatkundige en ekonomies-maatskaplike lewe vir meer dan een 'n toestand van nood en verdrukking ontstaan het, sal dit lig te begrype wees waarom soveel die prediking van Jesus aangeneem het. Alleen waar daar nood is, sal mens gryp na in ander uitweg. Alleen wanneer mens jouself nie kan help nie, en waar die middels wat jyself ken en gewoonlik gebruik ook nie kan help nie, sal jy gebruik maak van redmiddels wat ander aan jou voorhou. Eers moet daar by 'n mens wees kennis van eie nood en hulpeloosheid voordat jy elders uitredding sal soek.

In die feit dat daar by die Joodse volk, in die tyd net voor die geboorte van Jesus, ' $n$ verdieping ${ }^{28}$ ) van die Messiaanse verwagting gekom het, sien ons reeds 'n bewys dat hulle hulle eie nood ook op godsdienstige gebied erken het. Die feit dat hulle nasionale onafhanklikheid verlore was, dat hulle ekonomies verdruk was, het nie alleen hulle nasionale besef geskok nie, maar ook hulle godsdienstige besef

24) W. Fairweather: The Background of the Gospels. (Edinburgh 1908). p. 293.

25) vgl. DE ZwaAn, p. 143 en Fairweather, p. 295.

26) Openb. $20: 11$.

2i) Matth. 24:44.

28) Hierdie verdieping moet ons nie so verstaan asof daar helemal nuwe gesigspunte na vore gekom het nie - die elemente van 'n geestelike Godsryk soos wat dit by die Christendom volledig ontwikkel is, lê almal opgesluit in die Messiaanse profesieë, - maar die volk het dit nie altyd reg verstaan nie. 
diep getref. As gevolg van hierdie godsdienstige nood het daar in dié tyd dan ook verskillende Joodse sektes ontstaan, soos die Yweraars, die Sadduseërs, die Esseners en die Fariseërs, wat elkeen op hulle eie manier na 'n uitweg gesoek het.

Terwyl Klausner ${ }^{29}$ ) daarop wys dat die Esseners die naaste aan Jesus was, terwyl hulle in vrede wou lewe, geen aanstoot wou gee en teen besittings, slawe ens., was, wys FaIRwEATHer ${ }^{30}$ ) weer op 'n aanta! verskilpunte tussen die Esseners en Jesus: die Esseners is bv. asketies; Jesus ,eet en drink"; die Esseners lê alle nadruk op seremoniële reiniging. Jesus nie (sy dissipels eet met ongewaste hande); die Esseners verwerp die opstanding, ens. Hoe dit sy, die Esseners het seker hierin die simpatie van Jesus gehad, dat hulle gelet het op die regte verhouding tussen mens en mens. Dit is tog opvallend dat Jesus nêrens teen hulle optrek. Die verwaarlosihg van die verhouding tussen mens en mens, d.w.s. die beoefening van geregtigheid teenoor medemense was juis die groot oorsaak vir Jesus om teen die Fariseërs op te trek.

Die Fariseërs het alle nadruk op die verhouding tussen God en mens laat val, terwyl die verhouding tussen mens en mens verwaarloos is. Dit het by die gewone mense die indruk laat posvat, net soos by die profete van ouds, dat troue tempeldiens beter is as geregtigheid teenoor die mense. ${ }^{31}$ ) Hierteen het Jesus met alle mag opgekom. ${ }^{32}$ )

Die Fariseërs het met hulle beklemtoning van die verhouding tussen God en mens en die gevolglike reekse van gebooie, wat soos sware laste op die volk gedruk het, probeer om hulle self te red uit hulle godsdienstige nood, maar daardeur het hulle juis die nood van duisende verhoog. Daar was baie wat sig nie daarby kon neerlê nie dat seremoniële wette van meer waarde was as morele wette. Hulle moes veel soos in die tyd wat deur Jesaja 1 beskrywe word, toe die Here die volk moes aansê : „Ek verdra geen ongeregtigheid en feestyd nie." Meer as alles is dit die stywe wettisisme van die Fariseërs wat 'n vrugbare en ontvanklike bodem geskep het vir die Evangelie van Jesus met sy prediking van 'n verhouding van liefde tussen God en mens en tussen die mense onderling. Daar was in behoefte aan ware geregtigheid en hierdie ware geregtigheid het Jesus gepreek.

Maar laat ons nou nagaan hoe Jesus op die bodem gesaai het. Immers 'n vrugbare akker kon nog niks oplewer as die regte saad nie gesaai word, en as daardie saad nie op die regte manier gesaai word nie.

In die eerste plek moet ons daarop wys, dat Jesus 'n taal gepraat het wat die mense kon verstaan. Hy het gebruik gemaak van die

29) Klausner : p. 202.

30) FaIRWEATHER : p. 214.

31) Klausner: p. 216.

32) vgl. Matth. 23:13 v.v. 
elemente van waarheid wat daar was in die geloof van sy hoorders, en $\mathrm{Hy}$ het dit beklemtoon in die vorm en bewoordiginge wat aan sy hoorders bekend was. Ons kan maar dink aan die verwagting van die Joodse apokaliptiek dat die einde naby gekom het, en Jesus se eie bevestiging, dat die Seun van die Mens kom in die uur wanneer niemand dit verwag nie, ja selfs voordat die teenswoordige geslag verbygegaan het. ${ }^{33}$ )

Die beelde en vergelykings van Jesus was dan ook altyd uit die lewe van sy hoorders gegryp. Sy prediking het nie los van die lewe gestaan nie. Ons kan net verwys na sy opmerking dat twee mossies vir een stuiwer verkoop word en nogtans sal nie een van hulle op die aarde val buiten die wil van julle Vader nie. ${ }^{31}$ ) As ons daaraan dink dat mossies die voedsel van die armes was, uit wie sy hoorders juis grotendeels bestaan het, en dat stlke mossies vanweë hulle geringe prys self iets baie gerings voorgestel het, ${ }^{35}$ ) dan kan ons begryp dat hierdie vergelyking die harte van sy hoorders geraak het. Ook al die gelykenisse van Jesus was op so 'n realistiese wyse uit die lewe gegryp, dat dit eenvoudig moes boei.

Op die voetspoor van Jesus het sy dissipels ook met 'n prediking wat nie los van die lewe gestaan het nie, die wêreld ingetrek. Hulle het gebruik gemaak van die taal wat reeds by hulle hoorders bekend was. Daar is bv. die woorde parousie, evangelie, logos, ${ }^{36}$ ) waarop ons hier nie verder wil ingaan nie.

Ons wil slegs nog verwys na een voorbeeld by Paulus om te illustreer hoedat die heidense spraakgebruik en gewoontes aan die Evangelieprediking diensbaar gemaak is. Ons bedoel die praktyk van die loskoping van 'n slaaf deur een of ander godheid.

DEISSMANN beskrywe 'n godsdienstige plegtigheid waar 'n slaaf deur sy eienaar aan een of ander godheid verkoop word. Die vorige eienaar neem die slaaf na die tempel van die godheid en ontvang dan uit die skatkis die koopsom wat van te vore deur die slaaf uit sy spáargeld daar inbetaal is. So word die slaaf die eiendom en beskermling van die godheid, terwyl hy teenoor die hele wêreld, veral teenoor sy vorige eienaar, helemal vry is. ${ }^{37}$ )

So le Paulus daarop nadruk dat ons deur Christus losgekoop is van ons vorige eienaar, $\mathrm{nl}$. die sonde, en dus sy besitting word. ${ }^{38}$ ) Dit word nog des te treffender as ons daaraan dink dat die Griekse woord

33) vgl. FAjRWEATHER: p. 296 v.v.

34) Matth. 10:29.

35) vgl. Deissmann, p. 271.

36) Dit is myns insiens verkeerd om hier te praat van beïnvloeding deur die heidense opvattings. Ek sien dit eerder as gebruikmaking van die voorhande synde materiaal. Soos die Christendom die wêreld verower het, is ook die wêreldse taal aan die Christendom diensbaar gemaak.

37) DeIs SMANN, p. 326 v.v.

38) vgl. 1 Kor. 6:20, $7: 23$, Gal. 5:1, 1 Tim. $2: 6$ e.a. 
vir rantsoen nl. lutron ook gebruik was vir die koopsom by die loskoping van 'n slaaf, ${ }^{39}$ ) en dat hierdie plegtigheid van die loskoping van 'n slaaf ook nie helemal sonder 'n offerande gepaard gegaan het nie."

So is dit lig te begrype dat die eerste brief aan Korinthiërs wat so baie verwys na die loskoping deur Christus uit die slawediens van die sonde by die gemeentelede onder wie baie slawe was - 'n groot deel wąarskynlik vrygeloopte slawe - die harte diep getref het. Hulle het die beeld van vrygekooptes van Christus verstaan, en kon hulle daarom met die hele hart daarin verbly. Hulle het die taal van die prediking verstaan.

Maar Jesus en sy dissipels het nie alleen gepreek nie. Veral by Jesus geld dit, dat $\mathrm{Hy}$ gedoen en geleer het. ${ }^{+1}$ ) Die sterke invloed van Jesus is dan ook, naas sy prediking, vir 'n groot deel te danke aan sy manier van optrede.

Toe die Jode hulle dienaars uitgestuur het om Jesus gevange te neem, het hulle teruggekom met die rapport: ,Nooit het 'n mens so gespreek soos hierdie man nie." ${ }^{42}$ ) Dit is ook die getuienis van die dissipels toe hulle gesê het: .Na wie toe sa! ons gaan? U het die woorde van die ewige lewe." ${ }^{+13}$ )

Die feit dat almal wat Hom gehoor het deur Hom aangegryp was, was nie net aan die woorde van Jesus toe te skryf nie, maar veeleer daaraan dat $\mathrm{Hy}$ uit die diepste oortuiging van sy hart gespreek het Hy was altyd met innerlike ontferming bewoë oor die mense. Hy het die lyding en kruis van elke hart gepeil; $\mathrm{Hy}$ het ook die deugde in elke lewe raakgesien. So was sy verwysing na die arm weduwee, wat haar penning in die skatkis gooi, vir sy hoorders seker 'n openbaring van die waardering van sy hart ook vir die geringste deug in 'n lewe: en dit het hulle ook oortuig dat $\mathrm{Hy}$ 'n liefhebbende en waarderende Meester is.

Jesus het Hom dan ook nooit bokant sy hoorders gestel nie. Tenspyte van die smalende opmerkings van die geestelike leiers van die Joodse volk het $\mathrm{Hy}$ tog met sondaars en tollenaars saam geëet en gedrink.

Sy prediking was nie daarop gerig om die laste van sy volgelinge te verswaar nie, $\mathrm{Hy}$ wou dit verlig. Hy het gekom om salig te maak die wat verlore was. ${ }^{44}$ ) Daarom het $\mathrm{Hy}$ ook minder ophef gemaak oor die sogenaamde growwe sondes as wat $\mathrm{Hy}$ met sterk bewoordinge gewaarsku het teen skynheiligheid en geveinsdheid. ${ }^{45}$ )

39) Deissmann, p. 332

40) Deissmann, p. 334.

41) Hand. 1:1.

42) Joh. $7: 46$.

13) Joh. 6:68.

4) Matth. 18:11.

45) vgl. Otto Funcke: Jesus en de Menschen, p. 53 
Waar Hy na Homself verwys as nederig en sagmoedig van hart, terwyl sy juk sag is, en dit nie maar slegs woorde was nie, soos sy optrede teenoor so baie wat in hulleself verlore gevoel het bewys, moes dit 'n geweldige, byna hipnotiserende invloed op sy hoorders gehad het.

Jesus het nie alleen by sy hoorders op barmhartigheid ${ }^{48}$ ) en vergewensgesindheid ${ }^{47}$ ) aangedring nie; maar $\mathrm{Hy}$ het dit self ook beoefen. ${ }^{48}$ )

Hy het nooit persoonlike haat teen iemand gedra nie. Selfs met die wat Hom so uitdruklik vyandig gesind was, redeneer Hy kalm en bedaard, soos bv. met die Jode oor die doop van Johannes. Dink ook aan die kruiswoord: „Vader vergeef hulle, want hulle weet nie wat hulle doen nie."

In hierdie feit dat $\mathrm{Hy}$ gewillig was en te eniger tyd gereed was om met sy teëstanders, die Skrifgeleerders en Fariseërs, te redeneer, was ook 'n stimulus om die entoesiasme van sy volgelinge op te wek. $\mathrm{Hy}$ het nooit rede gehad om te twyfel nie. Altyd was Hy gereed met sy antwoord soos blyk uit die vraag oor die belasting en die geval van die oorspelige vrou wat gestenig moes word. ${ }^{49}$ ) Hy was dus nie maar 'n gewone "Am-ha-aretz," 'n plattelander met 'n geringe kennis nie. Hy het die wet en oorleweringe van sy volk geken, maar dit het Hom nie vreemd gemaak vir die "Amme-ha-aretz" nie. Hy het met hulle geleef on wou hulle dien. Aan sy dissipels het Hy gesê: „Ek is onder julle soos een wat dien." ${ }^{50}$ )

$\mathrm{Hy}$ het van elke geleentheid ten beste gebruik gemaak, ${ }^{51}$ ) en $\mathrm{Hy}$ kon ook altyd sonder aarseling optree, omdat $\mathrm{Hy}$ bewus was van sy roeping, en vas gestaan het in die oortuiging dat $\mathrm{Hy}$ 'n goddelike roeping vervul soos blyk uit sy bewering, dat $\mathrm{Hy}$ die brood van die lewe is, ${ }^{52}$ ) of by die instelling van die Nagmaal dat sy bloed uitgestort word tot vergiffenis van sondes vir baie. ${ }^{53}$ ) Omdat $\mathrm{Hy}$ van sy goddelike roeping bewus was, het $\mathrm{Hy}$ dit ook nooit nodig gevind om met enigeen ' $n$ kompromis aan te gaan nie. Die gesprek met Nikodemus is hiervan 'n treffende bewys. ${ }^{54}$ ) $\mathrm{Eg}$ menslik sou ons verwag dat Jesus die geleentheid sou aangryp om een van die invloedrykes aan sy kant te kry, maar daar is niks van toegewings nie. Jesus bly onversetlik in sy eis van die wedergeboorte. Hier kan die kerklike ampsdraers gerus

46) Luk. 10:37.

4i) Matth. $18: 35$

48) Joh. $8: 11$.

49) Matt. 22:15-22 en Joh. 8:3-11.

so) Luk. $22: 27$.

51) Volgens Markus word byna elke gesprek of gesegde van Jesus aan 'n voorval verbind.

52) Joh. $6: 48$

53) Matt. $26: 48$.

54) Joh. $3: 1-21$. 
'n voorbeeld aan Jesus neem. Immers, as Kerklike ampsdraers is ons dikwels geneigd om maar toegewings te mak teenoor invloedryke persone wat ook by ons kerk wil aansluit.

Samevattend kan ons oor die werk van Jesus sê dat die geheim van sy invloed, soos Woolf dit stel, lê in sy persoon en program. ${ }^{5 s}$ ) Sy program was nie anders as sy hart nie. Daarom het sy prediking van genade die skare getrek.

Wil ons nou in 'n paar woorde die vraag beantwoord waaraan die kragtige invloed van die optrede en prediking van Jesus toe te skryf is, dan moet ons sê: Hy het gekom in die volheid van die tyd, in 'n tyd toe al die volkere waarmee $\mathrm{Hy}$ en sy dissipels in aanraking sou kom verlangend uitgesien het na 'n Verlosser; en omdat die Evangelie wat Jesus as die ware Verlosser voorhou in 'n verstaanbare taal en met oortuiging gespreek is, daarom het dit by sovele ingang gevind en vir hulle verlossing gebring. So 'n geweldige invloed het die Evangelie in hulle lewe gehad, dat dit hulle in totaal ander mense verander het: Petrus het van 'n eenvoudige visser verander in 'n vurige Apostel; Paulus is van hoogaangeskrewene onder die geestelike leiers van die Joodse volk verander in 'n vervolgde, maar dit was vir hom nie te veel om te dra rie, want die genade van God was vir hom genoeg.

Die gees van pessimisme en van vrees vir in duistere toekoms wat so algemeen geheers het in die wêreld waar die Evangelie in die eerste jare van sy bestaan verkondig moes word, is deur die Evangelie van Jesus omgeskep in 'n oorwinningsgeloof; dit het gebring die diepgewortelde oortuiging dat mens 'n medewerker van God is wat die omstandighede van jou lewe ook al mag wees. ${ }^{56}$ )

Waar selfs die Jood, KLAuSNER, dan kom tot die erkenning dat die lewe en werk van Jesus ' $\mathrm{n} \mathrm{krag}$ en ' $\mathrm{n}$ invloed in die wêreld is waarvoor daar in die geskiedenis geen gelyke is nie. ${ }^{57}$ ) kan ons as Christene, veral as ons geestelike leiers onder ons volk is, vir ons gerus daarvan rekenskap gee of daar deur ons toedoen nog veel van hierdie krag en hierdie invloed in die werreld gevoel word.

Soos in die dae van die opkoms van die Christendom is daar ook vandag ' $n$ diepgevoelde behoefte aan verlossing onder die volkere van die wêreld. Die politieke en eknomies-maatskaplike nood van baie volkere het vir hulle in die laaste tientalle jare laat uitsien na allerlei vorms van verlossing. Die wêreld het verlangend uitgesien, en sien nog verlangend uit na ' $n$ beter basis van bestaan. Baie wag met ongeduld op die aanbreek van 'n goue eeu, en baie van die magtiges van die wêreld beloof te graag so in goue eeu. Nuwe ordes, nuwe basisse van bestaan, nuwe veiligheidskodes is oral aan die orde van

55) B. L. WoOLF, p. 83.

56) B. L. WOOLF, p. 208.

57) Klausner, p. 411. 
die dag. Die een gryp hierna en die ander daarna, maar al hierdie aanhangers en propageerders van baie ordes word ook heen en weer geslinger tussen die pole van hoop en vrees. Daar is in ons tyd ook ' $n$ diepgevoelde behoefte aan verlossing, al is dit merendeels net na tydelike veiligheid.

Dat ook op godsdienstige gebied die nood gevoel word, blyk uit die bedrywigheid van baie sektes, en selfs die opkoms van soveel nuwes.

So 'n akker soos die wêreld wat vandag voor ons lê, is inderdaad 'n vrugbare akker vir die Evangelie. Die nood van die mensheid, ook as gevolg van die verwoesting van die huidige oorlog, en hulle verlange na verlossing, moet dien as aansporing om die ewige verlossing in Christus Jesus as oorwinningslied oor die wêreld te laat heenklink.

Die prediking in die Kerk moet nie los staan van die lewe nie, en dit moet veral kom in ' $n$ taal wat die hoorders verstaan. Dit moet kom in die krag van volle geloofsoortuiging, maar dan veral ook moet die prediking nie daarop gerig wees om die laste van die hoorders te verswaar nie. Nie die verpligtinge maar die belofte van verlossing moet in die eerste plek beklemtoon word.

Wat die Kerk nodig het, is in die eerste plek nie teoloë nie, maar gelowiges. 'n Teologie wat groei uit die waaragtige geloofsoortuiging van die teoloog self alleen het waarde.

Ek wil hier graag 'n aanhaling uit Deissmann doen: Hy sê: .,Jesus is so eenvoudig, dat die kinders dit uitgeroep het van vreugde as $\mathrm{Hy}$ aankom, en dat die armste van gees Hom kon verstaan... Sy hele prediking is ' $n$ weerspieëling van 'n innerlike lewe wat vol ongebroke krag is, vol van reinheid, vol van toewyding aan God en sy menslike familie." ${ }^{58}$ )

Omdat Jesus se prediking gestaan het in die krag van die oortuiging van sy hart, omdat $\mathrm{Hy}$ gedurig weer versterk is deur die heilsame gemeenskap van sy Hemelse Vader - van jongsaf was $\mathrm{Hy}$ in die dinge van sy $\mathrm{Vader}^{59}$ ) - omdat $\mathrm{Hy}$ ten slotte met sy eie lewe bekragtig het, wat $\mathrm{Hy}$ beloof het, nl. toe $\mathrm{Hy}$ gesterwe het en begrawe is, toe Hy opgestaan en opgevaar het na die Hemel - daarom het sy prediking ook vrugte gedra; daarom het $\mathrm{Hy}$ 'n $\mathrm{krag}$ en ' $\mathrm{n}$ invloed in die wereld geword soos daar in die geskiedenis nog geen gelyke voor was nie en ook nie sal wees nie.

ANdries \}. NOLTE.

\footnotetext{
58) Deissmann, p. 386.

59) Luk. $3: 49$. 